\section{Training in Tuberculosis}

It is apparent that preventive measures taken against tuberculosis can never hope to be entirely successful without the active and intelligent co-operation of all those engaged in the practice of medicine. It may be questioned whether in many medical schools the doctors of the future are being adequately trained in the broader aspects of tuberculosis and in its clinical manifestations. Now that tuberculous cases have been almost entirely removed from the general teaching hospitals and relegated to special institutions, the training of the average medical undergraduate in tuberculosis is too often limited to an occasional visit to a chest clinic or a chest hospital. Here he is given the opportunity of examining a few patients suffering from advanced fibroid disease who are usually called "good teaching cases," and of listening to the sighing of amphoric breath sounds to the accompaniment of consonating crepitations and crack-pot notesarchaic physical signs of little vital clinical importance. It would be just as sensible to teach syphilis only by the demonstration of cases whose knee-jerks were absent and whose pupils had long since failed to react to light. Over-emphasis is laid on physical signs in the chest, which are often difficult or impossible to elicit in early pulmonary tuberculosis, whereas too little instruction is given on the general signs of tuberculous intoxication, common to all forms of the disease, which are often apparent to the patient's relatives and friends but overlooked by the doctor obsessed by his hunt for crepitations in the lungs. Again, the significance of history-taking in the diagnosis of tuberculosis is often insufficiently stressed; and yet the vast majority of patients repeat with variations the same history with the regularity of a theme in a symphony. In many medical schools, in short, the student is not educated in the natural history of tuberculosis, and he graduates with the idea that a slight knowledge of percussion and auscultation is sufficient equipment to enable him to grapple with the disease.

It is not surprising under these conditions that most cases are far advanced before they are diagnosed, and that meanwhile the patients may have grossly infected the youthful members of their family; that patients in need of complete rest, and perhaps collapse therapy, are simply advised to take a holiday in the country, or to change their occupation-from a sedentary one like that of a clerk to a strenuous one like that of a chicken farmer; and that the segregation of young children from open cases of tuberculosis is too often neglected even in circumstances where it is perfectly practicable.

I am only too conscious that there is nothing new in the foregoing remarks. Their object has been to focus discussion on some of the more important questions confronting those working for the prevention of tuberculosis. Owing to lack of time, certain subjects have not even been touched upon. It is generally recognized, for instance, that the open-air school is invaluable in raising the resistance of the delicate child to the disease, and it might be questioned why his more healthy brother should not share in its advantages. Again, the prevention of certain diseases which strongly predispose towards tuberculosis, such as silicosis, might be discussed. Lastly, the thorny problem of contact examination will doubtless find strong protagonists on either side. On the one hand its difficulties and impracticability may be stressed; on the other it may be claimed that contact examination, in its widest sense, is among the most important functions of the dispensary in the prevention of tuberculosis. With the latter view I cannot too strongly agree.

\section{FOUR CASES OF WEIL'S DISEASE INFECTED FROM THE SAME STREAM}

\author{
BY
}

\author{
KENNETH M. ROBERTSON, M.D., M.R.C.P. \\ Honorary Physician, Royal Hampshire County Hospital, \\ Winchester
}

Weil's disease is still rare enough in this country to make its diagnosis difficult unless the clinical manifestations are familiar and its possibility is borne in mind. It is a disease that is admittedly serious, and must threaten life whenever it appears. Different writers have recorded a mortality varying from 10 to 50 per cent. of all cases.

Specific treatment in the form of antiserum is available, and may be of great value, especially if administered in large doses and early in the disease. Davidson and Campbell (1934), in reporting a series of cases from Aberdeen, came to this conclusion: "Hence it appears to us that the clinical diagnosis in the early stage, before jaundice occurs, presents almost insuperable difficulties. Accordingly, the full benefit of serum treatment is unlikely to be realized."

During the past two years it has been my good fortune to have seen and treated four cases of leptospirosis. - In addition to these I have had under my care, and have investigated, three other possible but unproved cases. The experience gained by the study of each individual case, as it has appeared, has made possible the early diagnosis and treatment of the later cases, with, I maintain, the most satisfactory results.

The diagnosis should escape no one when jaundice, associated with nephritis and nitrogen retention, has followed upon an acute febrile illness in which headache; severe muscular pain, and scattered haemorrhages have been well marked. But all writers are agreed that at least 50 per cent. of these cases never do become jaundiced, while to wait for a laboratory diagnosis before starting serum treatment is to endanger the patient's life.

I feel, however, that in the very earliest stages the clinical picture is suggestive enough to make justifiable the use of serum before the diagnosis can be proved. Sudden onset of a severe illness, with headache, and quite frequently meningeal signs, high fever, severe pain, and great tenderness in the limb muscles; haemorrhages from the nose and the gastro-intestinal and urinary tracts ; and a most characteristic watery suffusion of the conjunctivae such as I personally have never seen in any other condition-these well-marked and very characteristic features should make it possible for the condition to be suspected. If in the presence of these symptoms and signs there is the history of a possible source of infection to which the patient has recently been subjected, as indeed there was in each of the proved cases here described, serum treatment should be instituted at once, without waiting for the laboratory to confirm the diagnosis. The very fact that all these cases-so far as I can discover the only cases of this particular infection that have been reported from South Hampshire-should have come under the eye of one practitioner would suggest that cases are occurring and are not being recognized, and that a fuller and wider knowledge of the infection and of its manifestations would bring to light other cases with, one would hope, a shortening of illness and even a saving of life. It is with this end in view that these cases are here reported in full. 


\section{Case I}

A healthy boy aged 15 complained of headache on the morning of Saturday, July 18, 1936. His temperature was $101^{\mathrm{c}}$ Throughout the day his condition deteriorated; headache became more severe, and he vomited. By evening his temperature was $103^{\circ}$. During the night he became violently delirious. On Sunday morning Dr. G. B. Wainwright asked me to see him. His temperature was $104^{\circ}$ and pulse 94 . Restless and complaining of severe headache, he had all the appearances of being seriously ill. It was noticed that his conjunctivae were suffused, and the possibility of a measles infection had been considered. The only other physical signs were those of severe meningeal irritation, a strongly positive Kernig's sign, and neck rigidity. Lumbar puncture was carried out at once, and the fluid, which was under pressure, appeared clear, and was in fact found to be perfectly normal. The boy"s headache, which had been relieved by lumbar puncture, returned later in the day, and his meningeal signs tended to increase, so that a further specimen of cerebrospinal fluid was obtained in the evening. but with precisely the same findings.

He was seen on Monday evening by Dr. Gordon Holmes, by which time his meningism had disappeared, and the only findings were a temperature of $103^{\circ}$ and absent deep reflexes. In considering the possible diagnosis Dr. Holmes suggested a deep-seated pneumonia, but mentioned that some cases of Weil's disease had been described which had an onset such as had been noted in this case.

For the next three days the patient remained very ill, with raised temperature, headache, and now very severe pain in the muscles of his legs and forearms. There had also been several small epistaxes.

On Thursday evening - the fifth day of his illness-slight conjunctival icterus was noted, while his urine was found to contain bile and albumin. He was seen by Dr. Hamilton Fairley next day, by which time his jaundice had deepened. The diagnosis of Weil's disease was confirmed on clinical grounds, and $40 \mathrm{c.cm}$. of anti-leptospiral serum was injected intravenously. Dr. Fairley took blood and urine with him to London, and later reported the following findings: "Van den Bergh-positive direct reaction, biphasic, 22 units ; blood urea-106 mg. per $100 \mathrm{c.cm}$.; blood count-white cells, 10,300 (91 per cent. polymorphonuclears). The blood serum gave a positive agglutination reaction, 1 in 3,000 dilution; the urine contained albumin, granular casts, bile salts, and bile pigments."

Twenty c.cm. of serum was injected into muscle on each of the next three days, during which time, though the jaundice deepened, the patient's general condition improved steadily; his temperature was normal by the tenth day. Details of the changes in his blood chemistry are given in Table $I$.

TABLE I.-Changes in the Blood Chemistry in Case I

\begin{tabular}{|c|c|c|c|}
\hline \multirow{2}{*}{ Date } & \multicolumn{2}{|c|}{ Van den Bergh } & \multirow{2}{*}{ Blood Urea } \\
\hline & Direct & Indirect & \\
\hline $24 / 7 / 36$ & Biphasic & 22 units & $106 \mathrm{mg}$. \\
\hline $27 / 7 / 36$ & $"$ & $56 \quad$. & $88 \mathrm{mg}$. \\
\hline $3 / 8 / 36$ & Delayed & 7.5 & $29 \mathrm{mg}$. \\
\hline
\end{tabular}

During the third week of his illness there was a rise of temperature up to $101^{\circ}$, and this was accompanied by swelling and extreme tenderness of the right parotid gland. So severe did this condition become that the gland was incised under nitrous oxide, and, though no pus was obtained, tension was relieved and the condition rapidly subsided. The boy remained jaundiced for about five weeks, and after a long and rather tedious convalescence made a complete recovery.

This patient, a keen swimmer, had been bathing throughout June and July in a swimming-pool through which runs the River Itchen. It was known that from time to time rats gained access to this pool.

\section{Case II}

Some twelve months or so later another healthy boy of 14 became ill. This boy had also often swum in the same bathing-pool as had Case I, but on account of a fractured metacarpal bone he had not done so for ten days preceding the onset of his illness. He was seen on Monday morning, July 26,1937 , by Dr. Wainwright, who found him then in perfect health and pronounced his hand as healed. He was taken suddenly ill the same evening with fever, headache, and epistaxis. His temperature rose to $103^{\circ}$, and on the next day he complained of abdominal pain, which was followed by a melaena stool. I was asked to see him on the evening of July 27, when I found this condition: temperature $102.8^{\circ}$, pulse 96, well-marked conjunctival suffusion, dried blood about the nose and mouth, and signs of meningeal irritation. His headache was relieved by lumbar puncture, when a pathological fluid was obtained. The various laboratory findings are given in Table II.

TABLE II-The Laboratory Findings in Case II

\begin{tabular}{|c|c|c|c|c|c|c|c|c|c|}
\hline \multirow{2}{*}{ Date } & \multirow{2}{*}{ Day } & \multirow{2}{*}{ V.d.B. } & \multicolumn{3}{|c|}{ C.S.F. } & \multirow{2}{*}{ Urine } & \multirow{2}{*}{ B.U. } & \multirow{2}{*}{$\begin{array}{l}\text { White } \\
\text { Count }\end{array}$} & \multirow{2}{*}{$\begin{array}{c}\text { Serum } \\
\text { Reaction }\end{array}$} \\
\hline & & & $\mathrm{Pn}$. & $\mathrm{Cl}$ & Cells & & & & \\
\hline $29: 7 / 37$ & 3 & $\begin{array}{c}\text { Nega- } \\
\text { tive }\end{array}$ & 20 & $\begin{array}{l}\mathrm{mg} . \\
690\end{array}$ & 6 & $\begin{array}{l}\text { Alb. } \\
\text { Casts } \\
\text { Red cells }\end{array}$ & mg. & $\begin{array}{c}5,100 \\
70 \% \text { polys }\end{array}$ & \\
\hline $31 / 7 / 37$ & 5 & . & 35 & 670 & 116 & $"$ & 60 & $\begin{array}{c}8,150 \\
74 \% \text { polys }\end{array}$ & $+1: 10$ blood \\
\hline $1 / 8 / 37$ & 6 & , & 40 & 690 & 226 & $"$ & 61 & & \\
\hline $3 / 8 / 37$ & 8 & , & & & & & & & $+1: 1,000$ blood \\
\hline $6 / 8 / 37$ & 11 & , & 30 & 690 & 9 & $"$ & 36 & & $\begin{array}{l}+1: 3,000 \text { blood } \\
+1: 30 \text { C.S.F. }\end{array}$ \\
\hline $10 / 8 / 37$ & 15 & & 30 & 720 & 4 & Trace alb. & 55 & ' & \\
\hline $17 / 8 / 37$ & 22 & & & & & Trace alb. & 26 & & \\
\hline
\end{tabular}

The provisional diagnosis of Weil's disease was made, and serum treatment was begun as soon as the material could be obtained. He had his first dose of serum on Wednesday morning, exactly thirty-six hours after the onset of his illness. He was given $20 \mathrm{c.cm}$. of serum intramuscularly on Wednesday, Thursday, Friday, and Saturday. During this time, as will be seen from the table, his meningeal condition was deteriorating, while his van den Bergh reaction remained negative. I was not then aware that jaundice was not an essential part of the picture, and I felt obliged to reconsider the diagnosis.

On Monday, August 2, Dr. Hamilton Fairley again came down in consultation, and confirmed the provisional diagnosis upon which treatment had been based. The next day I received a report from Major Brown that this patient's blood serum gave a weakly positive agglutination reaction. This blood had been obtained on the fifth day of his illness.

The boy was given a further $40 \mathrm{c.cm}$. of serum, and, except for a slight secondary rise in temperature during the third week, made an unusually rapid recovery.

\section{Case III}

On Saturday, June 25,1938 , a young man aged 20 was taken ill. He shivered, complained of retrosternal pain, and vomited, The next day he felt better, but was less well again on Monday. I first saw him at 11 a.m. on Monday, about forty hours after his first symptom.

His temperature was $103^{\circ}$, and his only physical signs were an injected throat and suffused eyes. Upon inquiry it was elicited that he had been bathing daily in another swimmingpool through which the River Itchen runs. He was admitted to hospital immediately, and treatment was started as soon as serum could be obtained. His blood chemistry, etc., are shown in Table III. During the next three days he developed extreme tenderness in the muscles of his calves and forearms, while his headache increased. There were several small 
haemorrhages from his nose. Serum was given as follows: on June 28, $40 \mathrm{c} . \mathrm{cm}$. ; June $29,40 \mathrm{c} . \mathrm{cm}$.; June $30,20 \mathrm{c.cm}$.; July 1,40 c.cm. The whole of this serum was injected into muscle. His general condition began to improve after the second dose, and on July 2 his temperature was normal.

TABLe III.-The Laboratory Findings in Case III

\begin{tabular}{|c|c|c|c|c|c|c|c|c|c|c|}
\hline \multirow{2}{*}{ Date } & \multirow{2}{*}{ Day } & \multirow{2}{*}{ V.d.B. } & \multicolumn{3}{|c|}{ C.S.F. } & \multirow{2}{*}{ Urine } & \multirow{2}{*}{ B.U. } & \multirow{2}{*}{$\begin{array}{l}\text { White } \\
\text { Count }\end{array}$} & \multirow{2}{*}{$\begin{array}{c}\text { Serum } \\
\text { Reac- } \\
\text { tion }\end{array}$} & \multirow{2}{*}{$\begin{array}{l}\text { Serum } \\
\text { Given }\end{array}$} \\
\hline & & & $\mathrm{Pn}$. & $\mathrm{Cl}$ & Cells & & & & & \\
\hline $27 / 6 / 38$ & 3 & - & mg. & \begin{tabular}{|c|}
$\mathrm{mg}$. \\
690
\end{tabular} & 4 & $\begin{array}{l}\text { Alb. }++ \\
\text { Casts } \\
\text { Red cells }\end{array}$ & mg. & $\begin{array}{c}11,600 \\
79 \% \text { polys }\end{array}$ & $\begin{array}{c}\text { Blood, } \\
\text { killed } \\
\text { g.pig }\end{array}$ & c.cm. \\
\hline $28 / 6 / 38$ & 4 & & & & & & & & $\begin{array}{l}\text { Nega- } \\
\text { tive } \\
1 \cdot 20\end{array}$ & 40 \\
\hline $29 / 6 / 38$ & 5 & + & & & & " & 121 & $\begin{array}{c}7,300 \\
72 \% \text { polys }\end{array}$ & & 40 \\
\hline $30 / 6 / 38$ & 6 & & 30 & 690 & 4 & & & & $\begin{array}{l}\text { Positive } \\
1: 3,000\end{array}$ & 20 \\
\hline $1 / 7 / 38$ & 7 & + & & & & Trace alb. & 100 & & & 40 \\
\hline $29 / 7 / 38$ & 35 & & & & & , & 30 & & & \\
\hline
\end{tabular}

Except for conjunctival icterus, which was noted on June 29, there was no clinical jaundice. He was discharged from hospital on July 9-the fourteenth day of illness-being quite free from symptoms. On July 21 he complained of pain in the neck and headache, and his temperature rose to $102^{\circ}$. In forty-eight hours this had subsided, and he was in bed for only three days. Since then he has remained well.

\section{Case IV}

This patient, a man aged 29 , who was employed as a worker in watercress beds some seven miles up the River Itchen, was admitted to hospital on March 7, 1937, with the following history.

On February 27 he had been taken ill, with high temperature, headache, vomiting, and pain in the back. The diagnosis of influenza had been made, and with treatment his temperature had fallen to normal. On March 3 he was noticed to be jaundiced, and this became rapidly more marked. Epistaxis occurred several times, and his urinary excretion became greatly diminished. He was sent into hospital by Dr. Kent with the tentative diagnosis of leptospirosis.

On admission he was apyrexial, had a pulse rate of 90 , was deeply jaundiced, and had a very parched dry tongue and old blood about his nose and mouth. Herpes were well marked. The liver was enlarged and there was a purpuric eruption ôver the trunk. He was quite rational and was able to give a clear account of his illness. He stated that he had passed very little urine for the last three days. A catheter was inserted, and $6 \mathrm{oz}$. of deeply coloured urine was withdrawn. This contained albumin, casts, and red cells. The white cell count showed a leucocytosis of 15,300 , with 85 per cent. polymorphs. The van den Bergh reaction was strongly positive, while his blood urea was recorded as $572 \mathrm{mg}$. per $100 \mathrm{c.cm}$. Blood taken on the day of admission - the ninth day of illness-gave a completely negative result to the agglutination test in all dilutions. Serum treatment had been started at once, and $20 \mathrm{c.cm}$. was injected intramuscularly on March $8,9,10$, and 11 .

Every effort was made to restart his urinary secretion, and he was given continuous intravenous saline, with hypertonic glucose every four hours. Hot packs, an electric cradle, and hot colonic lavage all proved of no avail, and he died on March 12-the fourteenth day of his illness.

The urine was repeatedly examined for leptospirae, but these were never demonstrated. Blood taken the day before his death gave a positive agglutination reaction at a dilution of 1 in 100 . Post-mortem examination revealed an enlarged liver in which leptospirae were demonstrated, and small haemorrhages distributed throughout the viscera. A very striking feature of this case had been that, in spite of the extraordinary figures recorded when the blood urea estimation was carried out, the patient remained able to talk intelligently to within twenty-four hours of his death. His blood chemistry is shown in Table IV.

TABLE IV.-The Laboratory Findings in Case IV

\begin{tabular}{|c|c|c|c|c|c|c|c|c|}
\hline \multirow{2}{*}{ Date } & \multirow{2}{*}{ Day } & \multirow{2}{*}{ Urine } & \multicolumn{3}{|c|}{ C.S.F. } & \multirow{2}{*}{$\begin{array}{l}\text { Blood } \\
\text { Count }\end{array}$} & \multirow{2}{*}{ B.U. } & \multirow{2}{*}{$\begin{array}{c}\text { Serum } \\
\text { Reaction }\end{array}$} \\
\hline & & & Pn. & $\mathrm{Cl}$ & Cells & & & \\
\hline $7 / 3 / 37$ & 9 & $\begin{array}{l}6 \text { oz. } \\
\text { Bile, alb., } \\
\text { casts, red } \\
\text { cells, no } \\
\text { leptospirae }\end{array}$ & mg. & $\mathrm{mg}$. & & $\begin{array}{c}15,300 \\
85 \% \text { polys }\end{array}$ & 572 & Negative \\
\hline $10 / 3 / 37$ & 12 & $2 \mathrm{oz}$ & & & & & 865 & \\
\hline $11 / 3 / 37^{*}$ & 13 & $4 \mathrm{oz}$. & 45 & 759 & 4 & & 685 & Positive \\
\hline $12 / 3 / 37$ & $\begin{array}{c}14 \\
\text { (died) }\end{array}$ & & & & & & & \\
\hline
\end{tabular}

* On examination at this date the cerebrospinal fluid was found to contain $660 \mathrm{mg}$. of urea per $100 \mathrm{c} . \mathrm{cm}$.

The three remaining cases were investigated when the possibility of Weil's disease was considered, but in none of them was the diagnosis confirmed in the laboratory.

\section{Case V}

A woman aged 55 was admitted to hospital at the end of August, 1937, very deeply jaundiced and with no other physical signs. The jaundice had been present a week, and had been preceded by abdominal pain, vomiting, and a temperature of $102^{\circ}$.

While in hospital she ran a little irregular fever up to $100^{\circ}$. Her urine contained albumin but no casts. Her van den Bergh reaction was strongly positive, while her blood revealed a massive leucocytosis-45,400 white cells (95 per cent. polymorphs). Her blood urea was $554 \mathrm{mg}$. per $100 \mathrm{c.cm}$. on admission and rose to $581 \mathrm{mg}$. on the day before death, four days later. Her serum was completely negative to the agglutination reaction. Post-mortem examination revealed an enlarged liver and scattered haemorrhages, but unfortunately no attempt to demonstrate leptospirae was made. In this case no suggestion of a possible exposure to infection was obtained.

\section{Case VI}

A woman aged 25 , a telephonist, in whom no history of likely infection could be obtained, was admitted to hospital on May 26, 1938. She had been taken ill ten days before with fever and pain in the back. The fever persisted for four days, and then gave way to vomiting. Jaundice was noticed on the seventh day of her illness. On admission she was very jaundiced and there was a small purpuric eruption over the trunk. No history of other bleeding could be elicited. The liver edge was palpable, but there were no other physical signs. The urine contained albumin, casts, and red cells, together with tyrosine crystals. A blood count showed 9,600 white cells, 74 per cent. being polymorphs. The blood urea was $49 \mathrm{mg}$. per $100 \mathrm{c.cm}$. The van den Bergh reaction was positive. The serum reaction was positive in 1 in 30 dilution. The serum reaction was repeated twice at intervals of one week, in the hope of obtaining a rising titre, but it remained completely negative at all dilutions. This patient was never seriously ill, and improved rapidly. Jaundice disappeared in three weeks from the onset. Urine became normal and the blood urea fell. No serum was administered.

\section{Case VII}

A boy aged 7 was admitted to hospital in July, 1938. He was slightly jaundiced, and had been ill with fever up to $102^{\circ}$ for eight days. His urine contained albumin, casts, and red cells, while his blood urea was slightly raised. His agglutination reaction was negative and blood count normal. His illness was slight, and he made an uneventful recovery. No serum was given. The boy, we were told, had frequently "paddled" in the River Itchen. 


\section{Commentary}

It will have been noticed that in each of the proved cases an obvious source of infection was recorded. All three boys who recovered were keen swimmers, and had been bathing frequently. in water which certainly might have been infected by rats. An unsuccessful attempt was made by the local health authorities to demonstrate infection in rats caught at these places, but it may be significant that, following an attempt to eliminate rats from the first bathing-pool, no further cases have come to light which could possibly have been infected there, while this summer's case occurred as the result of bathing in another pool in the same river. The fatal case, which is chronologically second on the list, but has been described last for convenience, was that of a man who by reason of his employment must often have been exposed to the risk of infection.

The striking difference in outcome and in length of illness which has been estimated in Cases II and III, where diagnosis was made early and serum given at once, as compared with Cases I and IV, where serum was not given until jaundice had appeared, cannot, I think, be regarded as a coincidence. Both the former cases appeared to have a severe infection, as judged by a well-marked meningitis in Case II and the early jaundice in Case III. Indeed, in the latter case it would seem fair to assume that the jaundice was aborted by serum given at once.

Each of the patients I was able to see at the onset of illness had that typical appearance of the eyes which has to be seen to be understood. Once seen it will always be recognized. In Case III one literally made the diagnosis "from the door," so striking was it. The whole of the bulbar conjunctiva appears inflamed, but there is less "anger" than in an inflammatory conjunctivitis and the injection seen in measles, while the slight conjunctival oedema imparts to the whole a watery look. The coloration is more pink than red. This appearance, when present, is evident within twenty-four hours of the onset, and may persist until the jaundice shows. It has been suggested that it may possibly indicate the site of infection in some cases. Schüffner (1934) describes a case in which a laboratory worker was infected by blood accidentally squirted into the eyes. Davidson and Smith (1936) found this appearance in 57 per cent. of their cases. In every case the blood urea was raised to figures that might well be disturbing, while those recorded in the fatal case, No. IV, are higher than I have seen noted elsewhere. Davidson, Campbell, Rae, and Smith (1934) report a blood urea of $349 \mathrm{mg}$., with death, and Swan and McKean (1935) record blood ureas of $387 / 600 \mathrm{mg}$. and $567 \mathrm{mg}$., both patients dying, while a case in which the blood urea was $285 \mathrm{mg}$. recovered. In the jaundiced cases the jaundice itself was suggestive, and was a bright yellow, almost orange-yellow. In fact, it was the colour of the jaundice in Case $\mathrm{V}$ which first made me suspect that that patient might be suffering from Weil's disease. Swan and McKean also noted this characteristic of the jaundice, and in describing their cases speak of "intense orange," " bright golden," etc.

The secondary rise of temperature so often describedSchüffner (1934), Davidson and Smith (1936), etc--appeared in each of the three cases which recovered. Davidson and Smith state that 50 per cent. of their cases showed this feature.

The unusual complication of parotitis which was a feature of Case I must, I think, be associated with the infection, coming as it did at the iime of the secondary rise. Willoughby and Shera (1934) descriis this as appearing on the tenth day in their case. J. D. Lendium (1936) noted the abolition of the deep reflexes in his cast: it will be remembered that this was found in Case I. During his convalescence Case III complained bitterly that he was losing his hair. This has frequently been recorded in the past (Fairley, 1934 ; Lendrum, 1936 ; etc.).

Leucocytosis with a shift to the left is so often found as to be a valuable point in differential diagnosis from catarrhal jaundice, in which this finding is absent. It was absent in Case II and was not at all well marked in Case III. Maxwell's (1935) case had only 6,600 white cells and a normal differential count.

Case III complained of retrosternal pain at the onset of the attack. This is of interest in that Jeghers, Houghton, and Foley (1935), in the report of the post-mortem examination of their case, record acute oesophagitis.

In Weil's disease the physician looks to the pathologist for proof of diagnosis. That being so, real doubt must be cast upon any diagnosis which does not carry with it confirmation from the laboratory. In order to receive the maximum help from the pathologist we must remember that leptospirae can be demonstrated in the blood stream during the first five or six days of the illness. In Case III blood taken on the third day of illness and injected intraperitoneally into a guinea-pig killed the animal after seven days. Leptospirae were demonstrated in the animal's liver.

The agglutination reaction does not become positive until the fifth or sixth day. In Case II it was weakly positive on the fifth day, while in Case III, negative on the fourth day, it was strongly positive by the sixth.

After the tenth day leptospirae may be demonstrated in the urine. From this it can be seen that laboratory diagnosis is unlikely before the seventh or eighth day of disease, while to withhold serum until this time may well mean disaster.

The agglutination reactions, which were all most generously carried out by Major H. C. Brown, show certain points of interest. The negative result as late as the ninth day in Case IV is unusual. This reaction was positive four days later, and the delay may have indicated an overwhelming infection. In this connexion it seems not unreasonable to suppose that in Case $\mathrm{V}$ the negative reaction obtained was not sufficient to exclude Weil's infection. The sudden appearance of a strongly positive reaction in Case III on the sixth day, after a completely negative finding forty-eight hours earlier, might be thought to be due to the large doses of serum given in the interim. In a personal communication Major Brown assures me that this is not the case, and he is supported by Professor Schüffner (1934), speaking of cases treated with serum and later proved not to be suffering from leptospirosis. In these cases the reaction remained negative. None of the cases in the present series gave a positive reaction in dilutions greater than 1 in 3,000 , whereas reactions at 1 in 30,000 are often recorded in untreated cases which recover. This is probably due to the use of serum, which, though curative, appears to depress the formation of active immunity in the body (Schüffner, 1934).

The diagnostic value of a positive reaction has been established. Davidson and Smith (1936) carried out the test on some 400 different sera and were unable to detect a single positive result, except in their clinical cases. This should be considered in connexion with Case VI, the serum of which gave a positive result at 1 in 30 , which was later not confirmed. Major Brown was unable to 
TABLE V.-The Principal Features of the Four Proved Cases

\begin{tabular}{|c|c|c|c|c|c|c|c|c|c|c|c|}
\hline Case and Age & $\begin{array}{l}\text { Mode of } \\
\text { Infection }\end{array}$ & $\begin{array}{r}\text { Day of } \\
\text { Jaundice }\end{array}$ & $\begin{array}{l}\text { Leuco- } \\
\text { cytosis }\end{array}$ & $\begin{array}{c}\text { Blood } \\
\text { Urea }\end{array}$ & Albumin & C.S.F. & Agglutination & Leptospirae & $\begin{array}{l}\text { Day of } \\
\text { First Dose } \\
\text { of Serum }\end{array}$ & $\begin{array}{l}\text { Total } \\
\text { Dose }\end{array}$ & $\begin{array}{l}\text { Length of } \\
\text { Illness }\end{array}$ \\
\hline Male (15) & Bathing & 5th, severe & + & $\begin{array}{l}\mathrm{mg} . \\
106\end{array}$ & + & Normal & $1: 3,000{ }^{+}$th day & - & 6th & $\begin{array}{l}\text { c.cm. } \\
100\end{array}$ & 12 wks. \\
\hline II Male (14) & & None & - & 95 & + & Pleocytosis 226 & $\begin{array}{l}1: 3,00011 \text { th day } \\
1: 105 \text { th day }\end{array}$ & - & 2nd & 120 & $5 "$ \\
\hline III Male (20) & , & 4th, slight & \pm & 121 & + & Normal & $1: 3,000{ }^{+}$th day & Blood 3rd day & $3 \mathrm{rd}$ & 140 & 4 , \\
\hline IV Male (29) & $\begin{array}{l}\text { Watercress } \\
\text { work }\end{array}$ & 5th, very severe & + & 865 & + & & $\begin{array}{c}1: 10013 \text { th day } \\
-9 \text { th day }\end{array}$ & Liver P.M. & 9 th & 80 & (Death) \\
\hline
\end{tabular}

explain this finding, and stated that it was unique in his experience. He was inclined to doubt the diagnosis of Weil's disease in this ease, though clinically the patient's condition was most suggestive of it. The dosage of serum to be given and the route of administration have never been laid down. From these cases it would appear that, so long as it is given early and in a dose of at least 40 c.cm. a day, it is as effective when injected into muscle as it is when put into the blood stream. It will be seen that the ultimate result and the length of illness are in direct proportion to the day of disease on which the serum is given-four and five weeks of illness in Cases II and III, compared with twelve weeks and death in Cases I and IV respectively. Serum was never used during the secondary rise of temperature, and this always settled without specific treatment.

In addition to specific treatment, which has already been described, it is important to maintain the urinary secretion. With this end in view all cases were treated with a high-carbohydrate protein-free fluid diet. The urine was maintained alkaline with potassium citrate, and, when necessary, glucose saline was given intravenously. The bowels, which tended to be constipated, were kept open with enemata. In Table $V$ the four proved cases have been compared. The salient and important features of their illness have been recorded and the value of early serum treatment has, I think, been demonstrated.

\section{Summary}

Four proved cases of Weil's disease are here recorded. Three of these occurred as the result of bathing in one river, while the fourth patient was infected from the same river, in which he worked. The possibility of early diagnosis is stressed, while the need for early specific treatment is demonstrated. Three other clinically suggestive but unconfirmed cases are reported. Certain points of unusual interest about the different cases are discussed.

It gives me great pleasure to record my indebtedness to Major H. C. Brown, who carried out all the agglutination tests in these cases and gave me much invaluable help. I am indebted also to Dr. Hamilton Fairley, whose opinion in Cases I and II was of the utmost value. The remaining laboratory investigations were carried out for me by Drs. Athole Ross and Charles Wrigley, honorary pathologists to the Royal Hampshire County Hospital: my thanks are due to them. I am very grateful to my partner, Dr. G. B. Wainwright, for his introduction to Cases $I$ and II.

\section{REFERENCES}

Davidson, L. S. P., Campbell, R. M., Rae, H. J., and Smith, J. (1934). British Medical Journal, 2, 1137.

and Smith, J. (1936). Quart. J. Med., n.s. 5, 263.

Fairley, N. Hamilton (1934). British Medical Journal, 2, 10.

Jeghers, H. J., Houghton, J. D., and Foley, J. A. (1935). Arch. Pathol., 20, 447 .

Lendrum, J. D. (1936). British Medical Journal, 2, 423.

Maxwell, J. (1935). Lancet, 2, 998.

Schüffner, W. (1934). Trans. roy. Soc. trop. Med. Hyg., 28, 7.

Swan, W. G. A., and McKean, J. A. (1935). Lancet, 2, 570.

Willoughby, W. G., and Shera, A. G. (1934). British Medical Journal, 2, 14

\section{MASTOID OPERATIONS}

\section{A FURTHER SURVEY}

BY

WALTER HOWARTH, M.A., M.B., F.R.C.S.

Surgeon to the Ear, Nose, and Throat Department, St. Thomas's Hospital

AND

\section{GEOFFREY BATEMAN, B.M., F.R.C.S. Chief Assistant to the Department}

In November, 1937, we published in this Journal (p. 954) the results of a series of cases operated on for chronic otorrhoea. This series did not include the cases cured by nasal or pharyngeal treatment, but only those requiring mastoid operations. We classified the operations used as Schwartze's, conservative, modified radical, and radical mastoid operations, and gave our definition of these methods. In reviewing these cases we were able to draw certain conclusions and to suggest indications for and contraindications to the various operations. During the past year we have applied these indications to our cases, and it may be of interest to publish the results.

There is such a slight division between acute mastoiditis and early chronic otorrhoea that can be cured by a Schwartze's operation that we will exclude this class of case from our analysis and confine ourselves to cases of well-established chronic otorrhoea. We have operated on eighty ears in seventy-nine patients, the one bilateral case having had two modified radicals. Of these, twelve had conservative mastoid, forty-five had modified radical, and twenty-three had radical mastoid operations.

\section{The Conservative Mastoid Operation}

The conservative mastoid operation when successful gives such satisfactory results that one is apt to attempt it even when contraindications are present, and in three of our cases we adopted this method in spite of finding cholesteatomatous material in the antrum. One of these has since been converted into a radical, and another requires re-operation. The third developed a postauricular abscess, which was drained, and eight months after operation the ear became dry, and has now been dry for a month, but it is doubtful if it will remain so. Including these three cases, of the twelve conservative operations, eight resulted in dry ears, of which two broke down again and one has been re-operated upon; four have never dried up, and one of these has been operated on again.

The six successful cases had central perforations, except one which had a low posterior marginal perforation with granulations growing from the tympanic ring external to the tympanic membrane. This patient has 